\title{
Pengetahuan Menginang berhubungan dengan Keluhan Rongga Mulut pada Lansia di Kabupaten Sampang Madura
}

\author{
(Menginang Knowledge Related to the Oral Complaint of the Elderly in Sampang Madura)
}

Emdat Suprayitno', Mujib Hannan², Alfi Laila²

1 Program Studi Ners Universitas Wiraraja

2 Program Studi Keperawatan Universitas Wiraraja

\begin{abstract}
Abstrak
Secara garis besar penyakit jaringan periodontal dapat disebabkan oleh dua faktor, yaitu lokal dan faktor sistemik. Faktor faktor tersebut dapat semakin diperparah dengan adanya faktor predipsposisi, seperti misalnya menginang. Tujuan penelitian ini adalah diketahuinya hubungan pengetahuan tentang menginang dengan keluhan rongga mulut pada lansia yang menginang di Desa Taman tahun 2019. Jenis penelitian yang digunakan penelitian analitik Cross Sectional. Sasaran dalam penelitian ini adalah lansia yang menginang di Desa Taman yang berjumlah 32 lansia. Metode pengumpulan data pengetahuan tentang menginang menggunakan kuisioner dan keluhan rongga mulut menggunakan observasi. Analisis penelitian ini menggunakan uji analisis chisquarae. Hasil dari uji statistic menggunakan Chi Square diperoleh nilai signifikan 0,045 yang berarti $\rho$ value $<0,05$. Oleh karena itu, dapat disimpulkan berdasarkan hasil uji Chi Square diatas yaitu terdapatnya hubungan pengetahuan tentang menginang dengan keluhan pada rongga mulut pada lansia yang menginang di Desa Taman Puskesmas Jrengik Kecamatan Jrengik Tahun 2019.
\end{abstract}

Kata kunci : menginang, keluhan rongga mulut, tingkat pengetahun

\section{Abstract}

Broadly speaking, periodontal tissue disease can be caused by two factors, namely local and systemic factors. These factors can be further aggravated by the presence of predisposition factors, such as host. The purpose of this study was to know relationship of betel knowledge with oral cavity complaints in the elderly in Taman village 2019. This study was cross sectional analytic research. The target in this study were elderly chewing betel in Taman Village, amounting to 32 elderly people. Methods of data collection knowledge of chewing betel used questionnaires and oral cavity complaints using observation. The analysis of this study used the is chi square test analysis. The analysis of is chi square test was significant which was $0,045 \quad(p<0,05)$. Conclusion was there was relationship of chewing betel with oral cavity complaints in elderly in the jrengik village public health center.

Keywords: chewing betel, knowledge, oral cavity complaints

Korespondensi (Correspondence) : Emdat Suprayitno, Program Studi Profesi Ners Fakultas Ilmu Kesehatan Universitas Wiraraja JI. Raya Sumenep-Pamekasan KM. 05 Patean, Sumenep, 69451, Email: emdat@wiraraja.ac.id

Lansia merupakan proses seseorang bertambah tua, merupakan interaksi yang kompleks dari segi biologis, psikologis, dan sosiologis. Umumnya setiap orang akan mengalami proses menjadi tua dan masa tua adalah masa hidup yang terakhir. Pada masa ini seseorang mengalami kemuduran fisik, mental, dan sosial hingga tidak melakukan tugasnya sehari-hari lagi dan bagi kebanyakan orang masa tua kurang menyenangkan. ${ }^{1}$ Kehilangan pada bagian gigi merupakan penyebab terbanyak menurunnya fungsi pengunyahan.

$$
\text { Kehilangan gigi juga }
$$

dapat mempengaruhi rongga mulut dan kesehatan umum sehingga akan mempengaruhi kualitas hidup seseorang secara keseluruhan. Kehilangan gigi bisa disebabkan oleh berbagai banyak hal. Penyebab terbanyak kehilangan gigi adalah akibat buruknya status kesehatan rongga mulut, terutama karies dan penyakit periodontal.2 $\mathrm{Di}$ Indonesia, penyakit periodontal merupakan penyakit kedua terbanyak diderita masyarakat $( \pm 73,50 \%)$, dan sekitar 4-5\%penduduk menderita penyakit periodontal lanjut yang menyebabkan gigi goyah dan lepas. ${ }^{3}$ Hasil Riset Kesehatan Dasar tahun 2013 di Provinsi Bali berdasarkan kelompok usia diperoleh data bahwa, kelompok usia 55 - 65 tahun dimiliki proporsi tertinggi dalam permasalahan kesehatan gigi dan mulut, yaitu $30,8 \%$.

Lansia yang menginang di Desa Taman Puskesmas Jrengik rata rata berumur 55-70 tahun dan mulai menginang sejak umur 18-20 tahun, sebagaian besar menginang karena disuruh orang tuanya sehingga sulit untuk mengubah kebiasan yang sudah terjadi sejak berpuluh -puluh tahun yang lalu. Pemeriksaan rongga mulut pada lansia yang menginang di Desa Taman Puskesmas Jrengik dengan jumlah 35 responden, diketahui $100 \%$ lansia dengan kondisi poket dalam dengan dangkal disertai masalah pada rongga mulutnya seperti resesi ginggiva, adanya lesi pada mukosa mulut, rusaknya gigi, ginggiva dan mokosa mulut, peradangan pada mokosa mulut, susah buka mulut, dan $95 \%$ lansia yang menginang mengeluh sakit pada rongga mulutnya. Hal ini menunjukkan tingginya persentase lansia yang menginang mengalami keluhan sakit pada rongga mulut di dusun Jiken, Taman, dan Tanjung Desa Taman Kecamatan Jrengik Kabupaten Sampang. Keluarganya sudah berupaya menghentikan kebiasaan menginang yang dilakukan lansia di dusun 
Jiken, Taman, dan Tanjung Desa Taman Kecamatan Jrengik Kabupaten Sampang.

Lansia diharapkan minimal mempunyai 20 gigi berfungsi, hal ini berarti bahwa fungsi pengunyahan mendekati normal, walaupun sedikit berkurang. Demikian halnya fungsi estetik serta fungsi bicara masih dapat dianggap normal dengan jumlah gigi minimal 20 buah. Menginang adalah proses pengunyahan bahan yang terdiri dari daun sirih, biji pinang, kapur, tembakau dan gambir. Kemudian selembar sirih dicampur dengan sedikit bahan-bahan tersebut lalu dikunyah. Menginang seperti ini bagi pecandunya merupakan sebuah kebutuhan yang tidak mungkin dihilangkan. Istilah lain menginang antara lain adalah bersugi, bersisik, menyepah, nyusur dan nginang. ${ }^{4}$

Komposisi dalam menginang terdiri atas daun sirih, gambir, buah pinang dan kapur. Akibat dari campuran tersebut menyebabkan gigi menjadi aus dan benwarna kemerahan, resesi gusi dan iritasi pada mukosa mulut. frekuensi menyirih dan cara menjaga kebersihan mulut juga sangat berpengaruh terhadap peningkatan jumlah penyakit pada sekitaran rongga mulut. ${ }^{5}$ Kebiasaan menginang mempunyai efek dapat mengikis elemen gigi sampai ginggiva, dan menyebabkan suasana basa didalam mulut sehingga dapat terjadi penumpukan kalkulus yang dapat menyebabkan peradangan pada gusi dan jaringan periodontal atau pendukung pada gigi. Jika dibiarkan tanpa adanya perawatan, gigi akan goyah dan tanggal dengan sendirinya. ${ }^{6}$

Kebiasaan menginang mempunyai beberapa efek buruk yang sangat merugikan, karena penggunaan kapur di dalam ramuan sirih yang menyebakan suasana basah didalam mulut sehingga dapat terjadinya penumpukan karies. Silikat yang terdapat dalam daun tembakau daf pengunyahan dalam waktu yang berangsur-angsur akan mengikis elemen gigi sampai gingiva. Kepercayaan bahwa mengunyah sirih dapat menghindari penyakit mulut seperti mengobati gigi yang sakit dan nafas yang tidak sedap kemungkinan telah mendarah daging pada lansia di Des Taman Puskesmas Jrengik. Padahal efek negative menginang dapat mengakibatkan penyakit periodontal dan gusi dengan adanya lesi lesi pada mukosa mulut. 3 Tujuan Penelitian ini yaitu untuk mengetahui hubungan pengetahuan menginang dengan keluhan rongga mulut pada lansia.

\section{Metode Penelitian}

Jenis penelitian yang digunakan adalah penelitian analitik., dengan menggunakan pendekatan Cross Sectioanal. Populasi adalah kumpulan semua elemen individu atau keseluruhan dari satu variabel yang menyangkut masalah yang diteliti dalam penelitian ini yaitu seluruh lansia menginang di Desa Taman Kecamatan Jrengik Kabupaten Sampang dengan jumlah 35 responden dengan simple random sampling. Instrumen penelitian yang digunakan untuk mengukur variabel pengetahuan lansia tentang menginang adalah quesioner. Instrumen penelitian yang digunakan untuk mengukur variabel keluhan rongga mulut adalah lembar wawancara dan lembar observasi.

\section{HASIL PENELITIAN}

Tabel 1. Distribusi Frekuensi Karakteristik jenis Kelamin lansia yang menginang di Desa Taman puskesmas jrengik kecamatan Jrengik 2019.

\begin{tabular}{llcc}
\hline No. & Jenis Kelamin & $\mathbf{F}$ & $\mathbf{\%}$ \\
\hline 1 & Laki-laki & 0 & 0 \\
2. & Perempuan & 32 & 100 \\
& Total & $\mathbf{3 2}$ & $\mathbf{1 0 0}$ \\
\hline
\end{tabular}

F, frekuensi; \%: prosentase

Mayoritas responden peneltiain ini adalah lansia perempuan. Responden ini 100\% mempunyai kebiasaan menginang.

Tabel 2 Distribusi usia lansia yang menginang di Desa Taman puskesmas jrengik kecamatan Jrengik 2019.

\begin{tabular}{llcc}
\hline No. & Usia & $\mathbf{F}$ & $\mathbf{\%}$ \\
\hline 1 & $56-60$ & 6 & 18,8 \\
2. & $61-65$ & 11 & 34,4 \\
3 & $66-70$ & 12 & 37,5 \\
4 & $71-75$ & 3 & 9,5 \\
& Total & $\mathbf{3 2}$ & $\mathbf{1 0 0}$ \\
\hline
\end{tabular}

$F$, frekuensi; \%: prosentase

Berdasarkan tabel 2 sebagian besar lansia yang menginang adalah usia $66-70$ tahun yaitu 12 responden $(37,5 \%)$.

Tabel 3 Frekuensi Pengetahuan Menginang Pada Lansia di Desa Taman Puskesmas Jrengik Kecamatan Jrengik Tahun 2019.

\begin{tabular}{llcc}
\hline No. & Kategori & $\mathbf{F}$ & $\mathbf{\%}$ \\
\hline 1. & Baik & 1 & 3,1 \\
2. & Cukup & 4 & 12,5 \\
3. & Kurang & 27 & 34,4 \\
& Total & $\mathbf{3 2}$ & 100 \\
\hline
\end{tabular}

$F$, frekuensi; \%: prosentase

Berdasarkan tabel 3 diketahui bahwa sebagian besar pengetahuan menginang pada lansia menginang adalah kurang yaitu 27 responden $(84,4 \%)$.

Tabel 4 Frekuensi Keluhan pada Rongga Mulut Lansia yang Menginang di Desa Taman Puskesmas Jrengik Kecamatan Jrengik Tahun 2019

\begin{tabular}{llcc}
\hline No. & Status kesehatan & $\mathbf{F}$ & $\mathbf{\%}$ \\
\hline 1 & Sakit & 7 & 21,9 \\
2. & Tidak Sakit & 25 & 78,1 \\
& Total & $\mathbf{3 2}$ & $\mathbf{1 0 0}$ \\
\hline
\end{tabular}

F, frekuensi; \%: prosentase 
Berdasarkan tabel 4 diketahui bahwa sebagian besar keluhan rongga mulut pada lansia yang menginang adalah sakit yaitu 25 responden $(78,1 \%)$.

Berdasarkan tabel 5.diketahui responden yang memiliki keluhan rongga mulut dengan katagori tidak sakit sebagian besar memliki pengetahuan dengan katagori kurang. Sedangkan responden yang memiliki keluahan rongga mulut sakit sebagian besar memiliki pengetahuan dengan katagori kurang. Hasil dari uji statistic menggunakan Chi Square diperoleh nilai signifikan 0,045 yang berarti $\rho$ value $<a(0,05)$, maka hipotesis (h1) diterima. Oleh karena itu, dapat disimpulkan berdasarkan hasil uji Chi Square diatas yaitu terdapatnya hubungan pengetahuan tentang menginang dengan keluhan pada rongga mulut pada lansia yang menginang di Desa Taman Puskesmas Jrengik Kecamatan Jrengik Tahun 2019.

\section{PEMBAHASAN}

1. Pengetahuan Lansia Yang Menginang di Desa Taman Kecamatan Jrengik Kabupaten Sampang

Berdasarkan hasil analisa data, sebagian besar lansia yang menginang di Desa Taman Kecamatan Jrengik Kabupaten Sampang memiliki pengetahuan kurang tentang menginang. Seluruh lansia yang menginang adalah usia 60 tahun lebih dan seluruhnya adalah perempuan. Pengetahuan tentang menginang merupakan salah satu usaha upaya promotif untuk mewujudkan status kesehatan gigi yang optimal. Pengetahuan atau kognitif merupakan domain yang sangat penting untuk terbentuknya tindakan seseorang. Perilaku yang didasari oleh pengetahuan akan bersifat lebih mempengaruhi daripada perilaku yang tidak didasari oleh pengetahuan. Perilaku manusia adalah semua kegiatan atau aktivitas manusia, baik yang dapat diamati langsung, maupun yang tidak dapat diamati oleh pihak luar. ${ }^{7}$ Mengenai perilaku menginang, kegiatan ini merupakan aktifitas rutin yang dilakukan oleh Iansia Desa Taman Kecamatan jrengik Kabupaten Sampang. Kebiasaan menginang di Desa Taman Kecamatan jrengik Kabupaten Sampang biasanya dilakukan setelah makan dan saat waktu luang. Lansia Desa Taman Kecamatan jrengik Kabupaten Sampang ini sebagaian besar menginang karena disuruh orang tuanya. Sehingga tidak ada respon untuk menolak karena sudah menjadi tradisi dari berpuluh - puluh tahun yang lalu.

Berdasarkan uraian yang terdapat dalam paragraf 2 , hal ini sesuai dengan teori L.Green yang menyatakan bahwa perilaku terdiri atas 3 faktor yang mempengaruhi perilaku yaitu predisposing, enabling, dan reinforcing. Berdasarkan dari 3 faktor yang mempengaruhi perilaku, faktor predisposing merupakan faktor yang dilihat oleh peneliti dalam melaksanakan penelitian. Dalam faktor predisposing ini mencakup pengetahuan dan sikap masyarakat terhadap kesehatan, tradisi dan kepercayaan masyarakat terhadap halhal yang berkaitan dengan kesehatan. Hasil pengamatan pada lansia tentang pengetahuan tentang menginang diketahui bahwa sebagian besar lansia menjawab salah pernyataan tentang menginang. Sehingga dapat disimpulkan bahwa tingkat pengetahuan lansia tentang menginang termasuk dalam kategori kurang.

Responden sebagian besar kurang memiliki pengetahuan mengenai menginang dan dampak kurang menginang. Kemungkinan dari kurangnya pengetahuan tentang menginang yaitu dari tingkat pendidikan, umur dan budaya. ${ }^{7}$ Lansia di Desa Taman mempercayai bahwa menginang dapat mencegahi penyakit mulut kemungkinan telah mendarah daging pada lansia di Desa Taman. Namun hal ini tidak sesuai dengan teori dari Dondy (2009) yang menyatakan efek negatif menginang dapat mengakibatkan penyakit periodontal dan gusi dengan adanya lesi lesi pada mukosa mulut. Oleh karena itu, pengetahuan lansia tentang menginang merupakan dasar yang penting dalam memahami dampak kurangnya tentang menginang. Sehingga, para lansia bisa mengetahui bagaimana menjaga rongga mulut.7 Pengetahuan merupakan dominan yang sangat penting untuk terbentuknya tindakan seseorang. Pengetahuan responden sangat mendasari terbentuknya perilaku yang mendukung kebersihan gigi dan mulutnya.

Tabel 5 Tabulasi Hubungan Pengetahuan Tentang Menginang Dengan Keluhan Pada Rongga Mulut Pada Lansia Yang Menginang Di Desa Taman Puskesmas Jrengik Kecamatan Jrengik Tahun 2019.

\begin{tabular}{|c|c|c|c|c|c|c|c|c|}
\hline \multirow{3}{*}{ No } & \multirow{3}{*}{$\begin{array}{c}\text { Kategori } \\
\text { Pengetahuan }\end{array}$} & \multicolumn{4}{|c|}{ Keluhan Rongga Mulut } & \multirow{2}{*}{\multicolumn{2}{|c|}{ Total }} & \multirow{3}{*}{$\rho$ value } \\
\hline & & \multicolumn{2}{|c|}{ Tidak Sakit } & \multicolumn{2}{|c|}{ Sakit } & & & \\
\hline & & $\mathrm{F}$ & $\%$ & $\mathrm{~F}$ & $\%$ & $\mathrm{~F}$ & $\%$ & \\
\hline 1. & Baik & 1 & 14,3 & 0 & 0 & 1 & 3,1 & \multirow{3}{*}{0,045} \\
\hline 2. & Cukup & 2 & 28,6 & 2 & 8 & 4 & 12,5 & \\
\hline \multirow[t]{2}{*}{2.} & Kurang & 4 & 57,1 & 23 & 92 & 27 & 84,4 & \\
\hline & Total & 7 & 100 & 25 & 100 & 32 & 100 & \\
\hline
\end{tabular}

, frekuensi; \%: prosentase; $p$ value, nilai kemaknaan 
Pendapat ini pun diperkuat dengan hasil penelitian yang dilakukan oleh Krista Veronica Siagian pada masyarakat Papua di Manado yang memiliki kebiasaan mengunyah biji buah pinang, skor kalkulus pada masyarakat yang menginang cenderung tinggi dikarenakan terbentuknya karang gigi yang disebabkan adanya stagnasi saliva dan terdapatnya fenolik pada komposisi bahan yang digunakan pada saat makan biji buah pinang. ${ }^{8}$ Penelitian Fatlolona 2013 juga menyebutkan bahwa terdapat hubungan antara frekueni menyirih dalam sehari dengan status kesehatan periodontal. Penelitian ini menunjukkan masih perlunya ditingkatkan promosi kesehatan akan dampak negatif dari kebiasaan menyirih secara terus menerus untuk merubah perilaku yang masih mempertahankan kebiasaan menyirih. ${ }^{9}$

\section{Keluhan Rongga Mulut Lansia Yang Menginang Desa Taman Kecamatan Jrengik Kabupaten Sampang}

Berdasarkan hasil pemeriksaan rongga mulut lansia yang menginang di Desa Taman, diketahui hampir sebagian besar lansia yang menginang mengalami rongga mulut dengan keluhan sakit. Hal ini sesuai dengan penelitian Samura (2009) menyatakan bahwa sebenarnya dari segi kesehatan, menginang dapat berdampak negatif bagi kesehatan gigi dan mulut, seperti mempercepat terjadinya karies pada gigi, kerusakan jaringan periodontal, sub mucous fibrosis dan yang paling bahaya menyirih dapat menimbulkan kanker pada mulut karena sugi sirih dan bahan-bahan lainnya mampu menghasilkan sel-sel yang mampu bermutasi. ${ }^{10}$ Berdasarkan dari hasil penelitian tentang Pemeriksaan rongga mulut pada lansia yang menginang di Desa Taman Kecamatan jrengik Kabupaten Sampang dengan jumlah 32 responden, diketahui sebagian besar lansia yang menginang memiliki kondisi poket dalam dengan dangkal disertai masalah pada rongga mulutnya seperti resesi ginggiva, hilangnya gigi dan mengeluh sakit pada rongga mulutnya. Kehilangan gigi merupakan penyebab terbanyak menurunnya fungsi pengunyahan. Kehilangan gigi juga dapat mempengaruhi rongga mulut dan kesehatan umum sehingga akan mempengaruhi kualitas hidup seseorang secara keseluruhan. Kehilangan gigi bisa disebabkan oleh berbagai hal seperti kurangnya status kesehatan rongga mulut, terutama karies dan penyakit periodontal. Hal ini sesuai dengan pernyataan dari Putri., dkk (2010) bahwa kebiasaan menginang mempunyai efek dapat mengikis elemen gigi sampai ginggiva, dan menyebabkan suasana basa didalam mulut sehingga dapat terjadi penumpukan kalkulus yang dapat menyebabkan peradangan pada gusi dan jaringan periodontal atau pendukung pada gigi. Jika dibiarkan tanpa adanya perawatan, gigi akan goyah dan tanggal dengan sendirinya. ${ }^{11}$ efek negative dari menyirih bisa menyebabkan penyakit periodontal yaitu penyakit inflamasi kronik rongga mulut yg umum dijumpai pada mukosa mulut jika didiamkan, dapat menyebabkan timbulnyalesi-lesi pada mukosa mulut, oral hygiene yang buruk dan menyebabkan atrofi pada mukosa lidah. ${ }^{12}$

3. Hubungan Pengetahuan Tentang MenginangDengan Keluhan Pada Rongga Mulut Pada Lansia Yang Menginang Di Desa Taman Puskesmas jrengik Kecamatan jrengik tahun 2019.

Berdasarkan hasil analisis data pada lansia yang menginang di Desa Taman, didapatkan hasil bahwa sebagian besar lansia yang menginang memiliki keluhan rongga mulut sakit. Lansia Desa Taman memiliki pengetahuan tentang menginang dalam kategori kurang lebih banyak dibandingkan lansia menginang yang memiliki pengetahuan tentang menginang dalam kategori baik dan cukup. Sehingga dapat disimpulkan ada hubungan antara pengetahuan tentang menginang dengan keluhan pada rongga mulut pada lansia yang menginang yang menginang di Di Desa Taman Kecamatan jrengik Kabupaten Sampang 2019.

Kerusakan rongga mulut lebih rentan pada lansia yang memiliki kebiasaan menginang. Ada faktor pendukung yang mempengaruhi tingkat kerusakan rongga mulut pada lansia menginang. Faktor dalam mulut yang berhubungan langsung dengan proses terjadinya kerusakan jaringan periodontal diantaranya: struktur gigi, plak, dan kebersihan rongga mulut.

Penyakit periodontal didefinisikan sebagai pendalaman sulkus ginggiva secara patologis dan merupakan salah satu tanda klinis dari penyakit periodontal yang penting. Plak sebagai penyebab utama terjadinya penyakit periodontal, akumulasinya banyak dipengaruhi oleh kondisi lokal jaringan rongga mulut, susunan gigi gerigi, diastema, perlekatan tali bibir/ frenulum bisa menjadi bagian yang memudahkan plak menumpuk yang berakibat timbulnya penyakit periodontal. Menurut putri dkk (2010) plak bisa menumpuk karena adanya kebiasaan menginang yang menyebabkan kondisi rongga mulut bisa menjadi basa. Akibat kondisi rongga mulut yang basa bisa terjadi penumpukan kalkulus dan berakibat pada jaringan periodontal. "Hal ini di karenakan kurangnya pengetahuan lansia tentang menginang di Desa Taman. Penegtahuan lansia tentang menginang akan mempengaruhi perilaku seseorang. Perilaku seseorang menurut L Green dipengaruhi faktor predisposisi seperti pengetahuan tentang menginang, faktor pemungkin dan faktor penguat. Oleh karena itu, tingkat pengetahuan merupakan faktor yang paling penting dalam terjadinya tindakan seseorang. Apabila pengetahuan lansia kurang maka besar kemungkinan perilakunya kurang, jika perilaku tersebut dibiarkan secara terus menerus maka hal ini akan berakibat pada 
rongga mulut lansia yang kurang pula. Hal ini sesuai dengan penelitian yang dilaukan oleh Aniati (2007) di desa pasi pinang kecamatan meureubo kabupaten aceh barat. Berdasrkan hasil uji statistik di peroleh adanya hubungan yang bermakna antara pengetahuan tentang makan sirih dengan kesehatan gigi dan mulut. Oleh karena itu, dapat disimpulkan bahwa semakin baik tingkat pengetahuan responden tentang makan sirih, maka semakin baik perilaku mereka dalam menjaga kesehatan gigi dan mulut sehingga akan terciptanya status kesehatan gigi baik. Begitupun pula sebaliknya. ${ }^{12}$ Kebiasaan menginang ini dianggap sama seperti menggosok gigi karena masyarakat percaya bahwa kebiasaan tersebut dapat menghilangkan noda pada gigi serta membersihkan sisa bahan menyirih yang terdapat pada sela gigi. Sedangkan kandungan bahan menyirih seperti kapur sirih mengandung kalsium hidroksida atau $\mathrm{Ca}(\mathrm{OH}) 2$. PH kalsium hidroksida yang tinggi akan menyebabkan rongga mulut bersifat basa dan menghasilkan suatu jenis oksigen reaktif berbentuk hydroxyl radical yang dapat merusak sistem oksidasi DNA sel mukosa penyirih dan mempercepat penumpukan plak pada gigi. ${ }^{13}$

\section{DAFTAR PUSTAKA}

1. Depkes R.I. Situsi dan analisis lanjut usia. Pusat data dan informasi Kementerian Kesehatan RI tahun 2014. Jakarta Selatan http://www.depkes. go.id/resources/download/pusdatin/info datin/infodatin-lansia.pdf diakses tanggal 20 Mei 2019

2. Putri $M H$, Herijulianti $E$, Nurjannah N. Ilmu pencegahan penyakit Jaringan keras dan jaringan pendukung gigi. EGC: Jakarta. 2010

3. Arini NW. 2012. Hubungan Menyirih Dengan Keadaan Jaringan Periodontal Pada Orang Yang Menyirih Di Banjar Sedana Mertha Kota Denpasar Tahun 2012. Jurnal Kesehatan Gigi.2012; 1 (2): 767.
4. Moeljanto R.D, Mulyono. Khasiat dan manfaat daun sirih. PT AgroMedia Pustaka: Jakarta. 2003. Hal. 2-3.

5. Musyafaatun, Arisdian T, Hastuti YD. Gambaran Karakteristik Biografikal Dan Budaya Menyirih Pada Lansia Wanita. Jurnal Ilmiah Stikes Kendal. 2017; 7(1): 17.

6. Putri $M H$, Herijulianti $E$, Nurjannah N. IImu pencegahan penyakit Jaringan keras dan jaringan pendukung gigi. EGC: Jakarta. 2010. Hal. 25.

7. Notoatmodjo, S. Kesehatan Masyarakat Imu Dan Seni. Ed.Revisi. PT Rineka Cipta: Jakarta. 2011. Hal. 109-155.

8. Veronika, Krista Siagian."Hubungan Status Kesehatan Peridontal dengan Menginang di Manado". 2016.

9. Fatlolona WO. Hubungan Status Kesehatan Periodontal dengan Kebiasaan Menyirih pada Mahasiswa Etnis Papua di Manado. e-GiGi, 2013; $1(2)$.

10. Samura JAP. Pengaruh Budaya Makan Sirih Terhadap Status Kesehatan Periodontal Pada Masyarakat Suku Karo Di Desa Biru-Biru Kabupaten Deli Serdang. 2009.

11. Putri MH, Herijulianti E, Nurjannah N. 2010. IImu pencegahan penyakit Jaringan keras dan jaringan pendukung gigi. EGC: Jakarta. 2010. Hal. 25.

12. Arniati. 2014. Pengaruh pengetahuan dan sikap masyarakat tentang makan sirih terhadap kesehatan gigi dan mulut pada masyarakat aceh di Desa Pasi kecamatan Meureubo Kabupaten Aceh Barat. 2014. http://repository.utu.ac.id /402/1/BAB\%20I_V.pdf tanggal $20 \mathrm{Mei}$ 2019

13. Kurniawati A. Pengaruh Kumur Ekstrak Daun Ungu Terhadap Jumlah Bakteri dalam Saliva. STOMATOGNATIC -Jurnal Kedokteran Gigi, 2018; 15(2), 43-4 